\title{
The effect of vitamin $D$ in rats maintained on diets with different mineral content but with the same calcium to phosphorus ratio of unity
}

\author{
BY R. B. HARRAND AND R. L. HARTLES \\ Department of Dental Sciences, School of Dental Surgery, \\ University of Liverpool \\ (Received 3 December 1969-Accepted 29 April 1970)
}

\begin{abstract}
I. Eight groups of ten weanling rats were maintained for $60 \mathrm{~d}$ on diets containing calcium and phosphorus in the ratio $I: I(w / w)$ at four different levels of mineral, namely $0.08,0.12,0.24$ and $0.36 \% \mathrm{Ca}$, with and without the addition of ergocalciferol.

2. Provision of vitamin $D$ increased final body-weight except at the highest level of mineral intake. Similarly, increasing the mineral intake increased final body-weight except at the highest level.

3. Vitamin $\mathrm{D}$ raised the serum $\mathrm{Ca}$ concentration at all levels of mineral intake but in the experiment as a whole had no significant effect on serum $P$ concentration. Serum Ca concentration was significantly higher at the two higher levels of mineral intake than at the two lower levels. Increasing dietary mineral caused a progressive increase in serum $\mathrm{P}$ concentration, except at the highest level of intake.

4. In general, the addition of vitamin $D$ to the diets had no effect on the fresh or dry weights of the humeri; there was an indication, however, that at the two lower levels of mineral intake, vitamin $\mathrm{D}$ reduced the fresh weight of bone. The addition of the vitamin caused a reduction in bone volume, and an increase in bone length, bone ash and the ratio of the weight of ash to the weight of organic matter in dry, fat-free bone. With increasing dietary mineral there was an increase in the value of all the bone measurements except bone volume, which was decreased.

5. The addition of vitamin $\mathrm{D}$ and increasing dietary mineral both caused an increase in tooth mass and ash content.

6. The ratios of tooth mass to bone mass, and tooth ash to bone ash were unaffected by vitamin $D$, but decreased with increasing mineral intake.

7. Histological examination of the bones showed that the animals receiving $0.08 \%$ of $\mathrm{Ca}$ and $P$ were markedly rachitic although the presence of vitamin $\mathbf{D}$ ameliorated the condition. When the dietary mineral intake was raised to $0.12 \% \mathrm{Ca}$ and $\mathrm{P}$ the animals were less severely rachitic and in the presence of vitamin $D$ the bones appeared normal.

8. The incisor teeth were abnormal at the two lower levels of mineral intake, but when vitamin $\mathrm{D}$ was provided, the histological appearance was improved. When the $\mathrm{Ca}$ and $\mathrm{P}$ level in the diet was $0.24 \%$, the incisal dentine appeared normal but the apical predentine was slightly wider than normal; addition of vitamin D produced teeth of normal appearance. The incisor teeth were normal in appearance in the remaining groups.

9. These results are compared with those obtained in two previous studies where the $\mathrm{Ca}$ to $P$ ratios were I : Io and 10:I (Harrand \& Hartles, 1968, 1969).
\end{abstract}

The effect of vitamin $\mathrm{D}$ on the bones and teeth of the rat varies with the state of calcium and phosphorus nutrition of the animal. We have reported on the effect of the vitamin at differing levels of mineral intake at two extremes of $\mathrm{Ca}$ to $\mathrm{P}$ ratio, namely I: Io and Io: I by weight (Harrand \& Hartles, r968, I969). The experiments now reported involved the maintenance of weanling rats on diets with and without vitamin $\mathrm{D}$, at four different levels of dietary minerals and with a constant $\mathrm{Ca}$ to $\mathrm{P}(\mathrm{w} / \mathrm{w})$ ratio of $\mathrm{I}: \mathrm{I}$. The four levels of dietary Ca were $0.08,0.12,0.24$ and $0.36 \%$. The effects of these variations in mineral intake and of adding vitamin $D$ were determined by 
measuring final body-weight, serum $\mathrm{Ca}$ and $\mathrm{P}$, weight, volume, length and ash content of the humeri, and weight and ash content of the mandibular incisor teeth. Histological examinations were made of the femurs and maxillary incisors.

\section{EXPERIMENTAL}

Animals. Eighty black and white weanling rats (24-28 d old) from our own colony were distributed in ten blocks of eight animals according to weight and sex. There were, therefore, five blocks of each sex, the weights of the animals within each block being as similar as possible.

Treatments. One animal from each block was distributed at random to each of the eight treatment groups designated I, I D, 2, 2D, 3, 3 D, 4, 4D. Each group consisted of five male and five female rats.

Diets. The basal diet contained sucrose ( $1340 \mathrm{~g}$ ), egg albumen (400 g) and groundnut oil (100 g). This mixture contained $0.026 \% \mathrm{Ca}$ and $0.06 \% \mathrm{P}$. The $\mathrm{Ca}$ and $\mathrm{P}$ contents of the diets were adjusted to the required levels by the addition of appropriate amounts of AR grade salts. In all diets, to each $184^{\circ} \mathrm{g}$ basal diet were added $80 \mathrm{~g}$ of a salt mixture containing neither Ca nor P (Harrand, Green \& Hartles, 1966). To each $1920 \mathrm{~g}$ batch of diet $\mathrm{I} \cdot 75 \mathrm{~g} \mathrm{CaCO}_{3}$ were added, raising the $\mathrm{Ca}$ content to $0.06 \%$, the same level as for $\mathrm{P}$.

The following salts were added to each batch of diet to achieve the differing levels of $\mathrm{Ca}$ and $\mathrm{P}$ at a ratio of $\mathrm{I}: \mathrm{I}$.

\begin{tabular}{|c|c|c|}
\hline Groups & $\underset{\text { (g) }}{\mathrm{CaHPO}_{4}}$ & $\begin{array}{c}\mathrm{KH}_{2} \mathrm{PO}_{4} \\
(\mathrm{~g})\end{array}$ \\
\hline $\begin{array}{l}\mathrm{I} \text { and } \mathrm{ID} \\
2 \text { and } 2 \mathrm{D}\end{array}$ & $\begin{array}{l}1.37 \\
4.08\end{array}$ & $\begin{array}{l}0.40 \\
1.18\end{array}$ \\
\hline 3 and $3 \mathrm{D}$ & $12 \cdot 26$ & 3.54 \\
\hline 4 and $4 \mathrm{D}$ & $20 \cdot 16$ & $5 \cdot 83$ \\
\hline
\end{tabular}

To each batch of diet were added $40 \mathrm{ml}$ water-soluble vitamin solution (Hartles \& Leaver, 1961) and $40 \mathrm{mg}$ biotin. In groups I-4 the groundnut oil contained vitamins $\mathrm{A}, \mathrm{E}$ and $\mathrm{K}$; in groups $\mathrm{ID}, 2 \mathrm{D},{ }_{3} \mathrm{D}, 4 \mathrm{D}$ the oil also contained ergocalciferol (Hartles \& Leaver, 196r).

The main features of the eight dietary treatments were as follows:

$\begin{array}{lccc}\text { Group } & \mathrm{Ca} & \mathrm{P} & \begin{array}{c}\text { Ergocalciferol } \\ (\mu \mathrm{g} / \mathrm{kg} \text { diet })\end{array} \\ \text { I } & (\%) & (\%) & \text { None } \\ \text { ID } & 0.08 & 0.08 & 208 \\ \text { 2 } & 0.08 & 0.08 & \text { None } \\ \text { 2D } & 0.12 & 0.12 & 208 \\ \text { 3 } & 0.12 & 0.12 & \text { None } \\ \text { 3D } & 0.24 & 0.24 & 206 \\ \text { 4 } & 0.24 & 0.24 & \text { None } \\ \text { 4D } & 0.36 & 0.36 & 205\end{array}$

Husbandry and techniques. The experimental regimen and analytical techniques were as described by Harrand \& Hartles (1968). The animals were maintained on the diets for $60 \mathrm{~d}$. 
Histological examinations. The femurs and maxillary incisors were treated and examined as described by Ferguson \& Hartles (1963, 1964).

\section{RESULTS}

The terminal body-weights and results of serum and bone analyses are given in Table I. The results for the incisor teeth are presented in Table 2.

The results were subjected to an analysis of variance in which the total treatment variation was divided into that due to treatments, that due to the blocks and the residual or error variation. The treatment variation was then further divided into that due to the addition of vitamin $\mathrm{D}$ to the diet, that due to alteration in dietary $\mathrm{Ca}$ and $\mathrm{P}$, and that due to the interaction of these two factors.

The following comparisons were made:
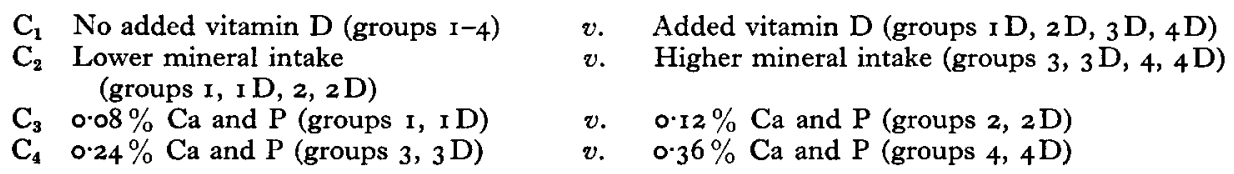

Consequently, the following interactions were determined: $C_{1}$ v. $C_{2} ; C_{1}$ v. $C_{3}$; $\mathrm{C}_{1}$ v. $\mathrm{C}_{4}$. The significance levels for all comparisons are shown in Table 3 .

Table I. Effect of vitamin $D$ and increasing mineral intake at a calcium to phosphorus ratio of $\mathrm{I}: \mathrm{I}$ on the composition of serum and bone of rats

\begin{tabular}{|c|c|c|c|c|c|c|c|c|c|}
\hline $\mathrm{Ca}$ content of diet $(\%) \quad \ldots$ & 0.0 & & $O . I$ & & & 24 & & 36 & \\
\hline Group* $\ldots$ & I & I D & 2 & $2 \mathrm{D}$ & 3 & $3 \mathrm{D}$ & 4 & $4 \mathrm{D}$ & SE \\
\hline Serum Ca $(\mu \mathrm{g} / \mathrm{ml})$ & $96 \cdot I$ & $116 \cdot 7$ & $82 \cdot 1$ & II $9 \cdot I$ & 104.5 & $109 \cdot 9$ & $108 \cdot 0$ & I 13.6 & 3.79 \\
\hline Serum $P(\mu \mathrm{g} / \mathrm{ml})$ & $34: 8$ & $32 \cdot 2$ & $49 \cdot I$ & 65.0 & $72 \cdot 7$ & $72 \cdot 7$ & $72 \cdot 6$ & $75 \cdot 4$ & 5.61 \\
\hline Fresh wt of humeri (mg) & $414 \cdot 6$ & $395 \cdot 4$ & $432 \cdot 4$ & $399^{\circ} 9$ & $460 \cdot 9$ & 470.4 & $488 \cdot 0$ & $489 \cdot 0$ & II.97 \\
\hline Volume of humeri $(\mu \mathrm{l})$ & $32 \times 9$ & $297 \cdot 0$ & $309 \cdot 5$ & $276 \cdot 7$ & $277 \cdot 1$ & $276 \cdot 1$ & $280 \cdot 2$ & $280 \cdot 0$ & 5.51 \\
\hline Length of humerus (mm) & $2 \mathrm{I} \cdot 2$ & $23 \cdot 1$ & $22 \cdot 1$ & $24 \cdot 6$ & $24 \cdot 7$ & $24 \cdot 7$ & $24 \cdot 9$ & 24.7 & 0.45 \\
\hline Fresh wt/volume $(\mathrm{g} / \mathrm{ml})$ & $x \cdot 29$ & $\mathrm{I} \cdot 34$ & $I \cdot 4 I$ & $\mathrm{I} \cdot 45$ & $1 \cdot 67$ & $I \cdot 71$ & $I \cdot 75$ & $1 \cdot 76$ & 0.06 \\
\hline Dry wt of humeri (mg) & $171 \cdot 0$ & $170 \cdot 0$ & 205.6 & $201 \cdot 3$ & 286.0 & $299 \cdot 2$ & $317 \cdot 3$ & 323.0 & 20.58 \\
\hline Wt of ash in humeri (mg) & $62 \cdot 5$ & $70 \cdot 6$ & $98 \cdot 5$ & $108 \cdot 2$ & $178 \cdot 3$ & I $89 \cdot 8$ & 203.6 & $209^{\prime} I$ & 19.10 \\
\hline Ash as $\%$ fresh humeri & $15 \cdot 3$ & $19 \cdot 6$ & $23 \cdot 6$ & $27 \cdot 4$ & $38 \cdot 7$ & $40: 4$ & $4 I \cdot 9$ & $42 \cdot 8$ & 3.43 \\
\hline Ash as $\%$ dry humeri & $36 \cdot 6$ & $41 \cdot 6$ & $48 \cdot 3$ & $53 \cdot 9$ & $62 \cdot 4$ & $63 \cdot 4$ & $64 \cdot 2$ & $64 \cdot 8$ & 3.48 \\
\hline Ratio $\mathrm{D}: \mathrm{R} \dagger$ & 0.71 & 0.77 & 0.92 & I. 04 & $I \cdot 64$ & $1 \cdot 76$ & $\mathbf{I} \cdot 88$ & I'94 & 0.16 \\
\hline Ratio $A: R \ddagger$ & 0.59 & 0.73 & 0.93 & $I \cdot I 8$ & $\mathrm{I} \cdot 66$ & $I \cdot 74$ & $I \cdot 80$ & $\mathrm{I} \cdot 86$ & 0.16 \\
\hline Final body-wt (g) & 133.5 & $172 \cdot 4$ & $175^{*} \mathrm{I}$ & 214.5 & 214.4 & $218 \cdot 5$ & $219^{\circ} 1$ & $217 \cdot 2$ & $9 \cdot 91$ \\
\hline $\begin{array}{l}\text { Fresh wt of humeri/body-wt } \\
(\mathrm{mg} / \mathrm{g})\end{array}$ & $3 \cdot 15$ & $2 \cdot 30$ & 2.50 & $x \cdot 88$ & $2 \cdot 19$ & $2 \cdot 18$ & $2 \cdot 26$ & $2 \cdot 30$ & 0.12 \\
\hline $\begin{array}{l}\text { Dry wt of humeri/body-wt } \\
(\mathrm{mg} / \mathrm{g})\end{array}$ & $I \cdot 30$ & 0.99 & $I \cdot 19$ & 0.96 & $1 \cdot 36$ & $1 \cdot 39$ & I·47 & $1 \cdot 52$ & 0.07 \\
\hline Wt ash in humeri/body-wt $(\mathrm{mg} / \mathrm{g})$ & 0.49 & $0.4 \mathrm{I}$ & 0.57 & 0.52 & 0.85 & 0.88 & 0.95 & 0.98 & 0.07 \\
\hline
\end{tabular}


Table 2. Effect of vitamin $D$ and increasing mineral intake at a calcium to phosphorus ratio of $\mathrm{I}: \mathrm{I}$ on the composition of the mandibular incisor tooth

(Mean values with standard errors for groups of five $\delta$ and five $q$ rats)

$\mathrm{Ca}$ content of diet $(\%) \quad \ldots$

Group* ...

Dry wt of incisor tooth (mg)

Wt of ash in incisor tooth $(\mathrm{mg})$

Ash as \% of dry tooth

Ratio A:R†

Dry wt of tooth/body-wt (mg/g)

Wt of ash in tooth/body-wt (mg/g)

Dry wt of tooth/dry wt of humerus

(mg/mg)

Wt of ash in tooth/wt of ash in

humerus ( $\mathrm{mg} / \mathrm{mg}$ )

\begin{tabular}{|c|c|c|c|c|c|c|c|c|}
\hline \multicolumn{2}{|c|}{0.08} & \multicolumn{2}{|c|}{0.12} & \multicolumn{2}{|c|}{0.24} & \multicolumn{2}{|c|}{0.36} & \\
\hline I & I D & 2 & $2 \mathrm{D}$ & 3 & $3 \mathrm{D}$ & 4 & ${ }_{4} \mathrm{D}$ & \\
\hline $58 \cdot 9$ & $5^{8 \cdot 4}$ & 53.5 & $60 \cdot 6$ & $65 \cdot 3$ & $66 \cdot 6$ & 68.9 & $67 \cdot 6$ & \\
\hline $43 \cdot 3$ & $42 \cdot 8$ & 38.0 & 447 & $48 \cdot 6$ & $49 \cdot 8$ & $5 \mathrm{I} \cdot 2$ & 50.7 & \\
\hline $73^{\circ} 6$ & $73 \cdot 3$ & $71 \cdot 0$ & $73^{\circ}$ & 74.5 & 74 & 74.5 & $75^{\circ} \circ$ & \\
\hline 79 & 2.75 & $2 \cdot 45$ & $2 \cdot 90$ & 2.92 & 2.97 & $2 \cdot 97$ & 3.07 & \\
\hline 45 & 0.34 & 0.31 & 0.29 & 0.32 & 0.32 & 0.33 & 3 & \\
\hline 33 & 0.25 & 0.22 & 0.2 & 0.24 & 0.24 & 0.24 & 0.25 & \\
\hline 69 & 0.69 & 0.52 & 0.60 & 0.46 & 0.45 & 0.44 & 0.43 & \\
\hline $4 x$ & $I \cdot 24$ & 0.78 & 0.83 & 0.55 & 0.53 & $0.5^{\mathrm{X}}$ & 0.49 & \\
\hline
\end{tabular}

* Denotes addition of vitamin D to the diet.

$\uparrow$ See footnote to Table $r$.

Table 3. Significance levels (P) for the effects on bones and teeth of rats of vitamin $D$, increased dietary calcium and phosphorus content at a constant ratio of $\mathrm{I}: \mathrm{I}$ and their interactions (I)

Serum Ca

Serum $P$

Fresh wt of humeri

Volume of humeri

Length of humerus

Fresh wt/volume

Dry wt of humeri

Wt of ash in humeri

Ash as \% fresh humeri

Ash as \% dry humeri

Ratio D:R*

Ratio A:R*

Final body-wt

Fresh wt of humeri/body-wt

Dry wt of humeri/body-wt

Wt of ash in humeri/body-wt

Dry wt of incisor tooth

Wt of ash in incisor tooth

Ash as \% dry tooth

Ratio A: $\mathrm{R}^{*}$

Dry wt of tooth/body-wt

Wt of ash in tooth/body-wt

Dry wt of tooth/dry wt of

humerus

Wt of ash in tooth/wt of ash in humerus

\begin{tabular}{|c|c|c|c|c|c|c|}
\hline & \multicolumn{6}{|l|}{ Groups } \\
\hline & \multicolumn{6}{|l|}{1,2} \\
\hline & $\begin{array}{c}v . \\
\text { groups }\end{array}$ & & $\begin{array}{c}\text { Group I } \\
v .\end{array}$ & & $\begin{array}{c}\text { Group } 3 \\
v .\end{array}$ & \\
\hline Vitamin D & 3,4 & I & group 2 & I & group 4 & I \\
\hline 0.001 & 0.05 & 0.001 & NS & 0.05 & NS & NS \\
\hline NS & 0.001 & NS & 0.001 & 0.025 & NS & NS \\
\hline NS & 0.001 & 0.025 & NS & NS & 0.025 & NS \\
\hline 0.01 & 0.001 & 0.01 & 0.025 & NS & NS & NS \\
\hline 0.001 & 0.001 & $0.00 \mathrm{r}$ & 0.001 & NS & NS & $\mathrm{NS}$ \\
\hline 0.001 & 0.001 & NS & 0.001 & NS & 0.001 & NS \\
\hline NS & O.OOI & NS & 0.001 & NS & 0.001 & NS \\
\hline 0.025 & $0.00 I$ & NS & $0.00 \mathrm{r}$ & NS & 0.001 & NS \\
\hline 0.001 & 0.001 & 0.01 & 0.001 & NS & 0.001 & NS \\
\hline 0.001 & 0.001 & 0.001 & 0.001 & NS & 0.05 & NS \\
\hline 0.001 & 0.001 & NS & 0.001 & NS & 0.001 & NS \\
\hline 0.001 & 0.001 & 0.001 & $0.00 \mathrm{r}$ & 0.05 & 0.001 & NS \\
\hline 0.001 & 0.001 & 0.001 & 0.001 & NS & NS & NS \\
\hline 0.001 & 0.001 & 0.001 & 0.001 & NS & NS & NS \\
\hline 0.001 & 0.001 & 0.001 & 0.025 & NS & $0.00 \mathrm{I}$ & NS \\
\hline NS & 0.001 & $0.00 x$ & 0.001 & NS & 0.001 & $\mathrm{NS}$ \\
\hline 0.05 & 0.001 & 0.05 & NS & O.OI & 0.05 & NS \\
\hline 0.01 & 0.001 & 0.025 & 0.05 & 0.001 & 0.05 & NS \\
\hline 0.05 & 0.001 & NS & 0.05 & 0.01 & NS & NS \\
\hline 0.025 & 0.001 & NS & NS & 0.01 & NS & NS \\
\hline 0.001 & 0.01 & 0.001 & 0.001 & 0.001 & NS & NS \\
\hline $0.0 \mathrm{r}$ & 0.025 & $0.00 \mathrm{r}$ & 0.001 & 0.001 & NS & NS \\
\hline NS & 0.001 & 0.01 & 0.001 & 0.01 & NS & NS \\
\hline NS & 0.001 & NS & 0.001 & 0.001 & NS & NS \\
\hline
\end{tabular}

NS, not significant.

* See footnote to Table I. 


\section{Histological examination}

Femurs. In groups $\mathrm{I}$ and I D $(0.08 \% \mathrm{Ca}$ and $\mathrm{P})$ the bones were markedly rachitic. The epiphyseal cartilage was wide and irregular. There was much osteoid in the shafts and trabeculae. The cortex of the shaft and the trabeculae were thin. At this level of mineral intake, addition of vitamin $\mathrm{D}$ caused an improvement in the appearance of the bones; the epiphyseal disc was only slightly wider than normal but there was still much osteoid present. Raising the mineral intake to $0.12 \% \mathrm{Ca}$ and $\mathrm{P}$ (group 2) did not prevent rachitic signs, the epiphyseal cartilage was still wider than normal, osteoid was present but the trabeculae and the cortex of the shaft were thicker than in groups I and I D. When vitamin $\mathrm{D}$ was added to the diet (group $2 \mathrm{D}$ ) the bone appeared normal. The bones in all other groups were normal in appearance.

Incisor teeth. The teeth from group I animals were severely affected. In the apical region the predentine was twice the width of the dentine, which contained many unfused calcospherites; this lack of fusion was also present in the incisal dentine. When vitamin $\mathrm{D}$ was added to the diet (group I D) there was some improvement to the apical region, the predentine was now only one-third as wide as the dentine, and the incisal dentine, although the pattern of mineralization was irregular, showed fewer unfused calcospherites.

The teeth from group 2 animals $(0.12 \% \mathrm{Ca}$ and $\mathrm{P})$ were similar in appearance to those from group I. Addition of vitamin $\mathrm{D}$ to the diet (group $2 \mathrm{D}$ ) caused an improvement in appearance similar to that in group I D.

Raising the mineral intake to $0.24 \mathrm{Ca}$ and $\mathrm{P}$ (group 3) resulted in a dramatic improvement; the apical dentine was almost normal and the incisal region was normal in appearance. Addition of vitamin D (group $3 \mathrm{D}$ ) produced an almost normal tooth. The teeth in groups 4 and ${ }_{4} \mathrm{D}$ were normal in appearance.

\section{DISCUSSION}

These experiments complete a series of three studies in the rat designed to provide information concerning the effects of vitamin $\mathrm{D}$ and the level of dietary $\mathrm{Ca}$ and $\mathrm{P}$ on the serum, bones and teeth. We have already reported on the effects of vitamin D at four different dietary levels of mineral at constant $\mathrm{Ca}$ to $\mathrm{P}$ ratios of $\mathrm{I}: \mathrm{r} O$ and $\mathrm{ro:} I$ (Harrand \& Hartles, I968, 1969). We have now obtained similar results when the Ca to $\mathrm{P}$ ratio was $\mathrm{I}: \mathrm{I}$. The diets used ranged from those grossly deficient in $\mathrm{Ca}$ and $\mathrm{P}$ $(0.08 \%)$ to those containing 'adequate' amounts $(0.36 \%)$.

\section{Growth of animals}

Comparison of the final body-weights of animals receiving vitamin $\mathrm{D}$ with those of the animals denied the vitamin revealed a significant increase in weight attributable to the addition of vitamin D to the diet. However, inspection of the results (Table I) shows that this increase was confined to the two lower levels of mineral intake (groups I, ID, 2 and $2 \mathrm{D}$ ). The animals receiving the two higher levels of mineral were significantly heavier than those receiving the diets containing less mineral. 


\section{Serum $C a$ and $P$}

The addition of vitamin $\mathrm{D}$ to the diet caused a significant increase in serum $\mathrm{Ca}$ concentration, an effect which was greatest at low levels of mineral intake. Comparison of groups I and 2 with groups 3 and 4 shows that the increasing mineral intake caused an increase in serum $\mathrm{Ca}$ but at a lower level of significance $(P<0.05)$. This effect is due to the action of the increased mineral in the absence of vitamin $\mathrm{D}$. In the presence of the vitamin, increasing the mineral in the diet did not increase the serum $\mathrm{Ca}$ concentration. This is reflected in the highly significant interaction (Table 3).

The effect of the addition of vitamin $D$ on serum $P$ concentration was not significant, whereas increasing dietary mineral content had a highly significant effect. Thus at a $\mathrm{Ca}$ to $\mathrm{P}$ ratio of $\mathrm{I}: \mathrm{I}$, serum $\mathrm{Ca}$ concentration was unaffected by increased dietary mineral, provided that the diet contained vitamin D. Serum $P$ concentration on the other hand increased with increasing dietary mineral both in the presence and absence of the vitamin.

\section{Bones and incisor teeth}

A comparison of the results for all groups with and without vitamin $D$ reveals several interesting effects of the vitamin. In general, vitamin D had no significant effect on the fresh weight or dry weight of the humeri, but examination of Table 1 shows that at the two lower levels of dietary mineral the vitamin reduced the fresh weight of the humeri and at the two higher levels of mineral the fresh weight was increased. This effect almost disappeared for the dry weight of the humeri.

The weight of ash deposited in the humeri was increased in the presence of vitamin $D$ by a small but significant amount. The percentage of ash, the ratio of ash to dry fat-free organic matter, the ratio of dry fat-free mass to water plus fat in the fresh bone and the length of the humeri were all significantly increased in the presence of vitamin $\mathrm{D}$. The volume of the humeri was significantly reduced when vitamin $\mathrm{D}$ was added to the diet, but examination of Table I shows that this effect was confined to the two lower levels of dietary mineral. Consequently, the crude density of the bone (fresh weight/volume) was significantly raised by the addition of the vitamin, but this increase at the lower levels of mineral intake was largely due to a decrease in water and fat content and not merely to an increase in the deposition of bone salts. The ratios of bone mass (both fresh and dry fat-free) to body-weight were significantly lower in the presence of vitamin $\mathrm{D}$, but again the effect was confined to the two lower levels of dietary mineral, showing that in these circumstances the vitamin increased bodyweight more than bone weight.

Increasing the dietary mineral content caused significant increases in fresh weight, dry weight, weight of ash, percentage of ash, ratio of ash to dry fat-free organic matter and ratio of dry fat-free mass to water + fat in the fresh bone in the humeri. The volume of the humeri was significantly reduced with increasing mineral intake and the length significantly increased except at the highest level of intake.

The relative effect of increasing dietary mineral is of interest. When the two higher levels of mineral are compared with the two lower, there is a significant fall in the ratio 
of fresh weight of bone to body-weight, indicating that the increase in total bone mass was less than the increase in final body-weight. On the other hand, a similar comparison of dry weight and weight of ash with body-weight shows a significant rise in the ratio, showing that with increasing mineral intake the absolute amounts of fat-free dry bone and bone ash were increased to a greater extent than that of body-weight. This is a reflection of the fact that when dietary mineral is in short supply much of the bone mass is fat and water.

The provision of vitamin D had a small effect of low significance in increasing dry weight, weight of ash, percentage of ash and ratio of ash to dry fat-free organic matter of the incisor teeth. Inspection of Tables 2 and 3 shows that these effects were mainly confined to those animals receiving $0.12 \% \mathrm{Ca}$ and $\mathrm{P}$ (groups 2, $2 \mathrm{D}$ ). Increasing the dietary mineral resulted in an increase in total mass and weight of ash. The percentage of ash and A: R ratio increased with increasing mineral intake up to $0 \cdot 24 \% \mathrm{Ca}$ and $\mathrm{P}$.

\section{Comparison of results obtained at three different $C a$ to $P$ ratios}

It is of great interest to compare the results obtained with those from earlier studies carried out under similar conditions and experimental design (Harrand \& Hartles, ı 968 , i969).

In order of ascending dietary $\mathrm{Ca}$ to $\mathrm{P}$ ratio, the three series of experiments were as follows:

\begin{tabular}{rllll}
\multicolumn{5}{c}{$\mathrm{Ca} \%$ in diet } \\
\cline { 2 - 4 } Ca to P ratio I : IO & 0.08 & 0.12 & 0.23 & 0.32 \\
$I: I$ & 0.08 & 0.12 & 0.24 & 0.36 \\
$I 0: I$ & 0.8 & 1.2 & 2.3 & 3.3
\end{tabular}

At the lowest levels of dietary intake there is an absolute deficiency of $\mathrm{Ca}$ at a $\mathrm{Ca}$ to $P$ ratio of $I: 10$, and of $P$ when the ratio is $10: I$.

Growth. When the Ca to $\mathrm{P}$ ratio is $\mathrm{I}: \mathrm{I}$ o vitamin $\mathrm{D}$ enhances growth at all levels of mineral intake studied; when the ratio is $I: I$ the vitamin enhances growth only when there is a deficiency of dietary mineral. When the diet contains adequate $\mathrm{Ca}$ but is deficient in $\mathrm{P}$ (Ca to $\mathrm{P}$ ratio of $\mathrm{IO}: \mathrm{I}$ ) addition of vitamin $\mathrm{D}$ causes a reduction in bodyweight; increasing the absolute dietary mineral at the same $\mathrm{Ca}$ to $\mathrm{P}$ ratio reverses this effect (see Fig. I).

In relation to mineral intake an excessive amount of $\mathrm{P}$ in the $\operatorname{diet}(\mathrm{Ca}$ to $\mathrm{P}=\mathrm{I}: \mathrm{IO}$ ) appears to be toxic and has a deleterious effect on growth, whereas an abundance of $\mathrm{Ca}(\mathrm{Ca}$ to $\mathrm{P}=\mathrm{IO}: \mathrm{I}$ ) does not have this effect. Although a statistical comparison between the three studies would not be valid, certain inferences can be drawn. Fig. I indicates that the greatest final body-weight was achieved when the diet contained $0.36 \% \mathrm{Ca}$ and $\mathrm{P}$. At low levels of dietary mineral a $\mathrm{Ca}$ to $\mathrm{P}$ ratio of 10 : $\mathrm{I}$ results in a lower final body-weight than when the Ca to $\mathrm{P}$ ratio is $\mathrm{I}: \mathrm{IO}$. With increased mineral intake the converse is true. If weight gains during the $60 \mathrm{~d}$ experimental period, rather than final body-weights, are compared, the patterns are almost identical.

Serum $\mathrm{Ca}$ and $\mathrm{P}$. Fig. 2 shows in diagrammatic form the effect of vitamin $\mathrm{D}$ and increasing dietary mineral intake on serum $\mathrm{Ca}$ and $\mathrm{P}$ concentrations in the three series 
of experiments. There is a marked rise in serum $\mathrm{Ca}$ concentration as the dietary $\mathrm{Ca}$ to $P$ ratio changes from $I: 10$ through $I: I$ to $10: I$, accompanied by a fall in serum $P$ concentration.

Vitamin $\mathrm{D}$ exerts its greatest effect on raising serum $\mathrm{Ca}$ concentration (calcaemic effect) when there is a deficiency in absolute terms of either $\mathrm{Ca}$ or $\mathrm{P}$; the effect of the vitamin on $\mathrm{Ca}$ concentration is minimal when the dietary $\mathrm{Ca}$ or $\mathrm{P}$ content rises to 0.24 or $0.32 \%$ irrespective of the $\mathrm{Ca}$ to $\mathrm{P}$ ratio.

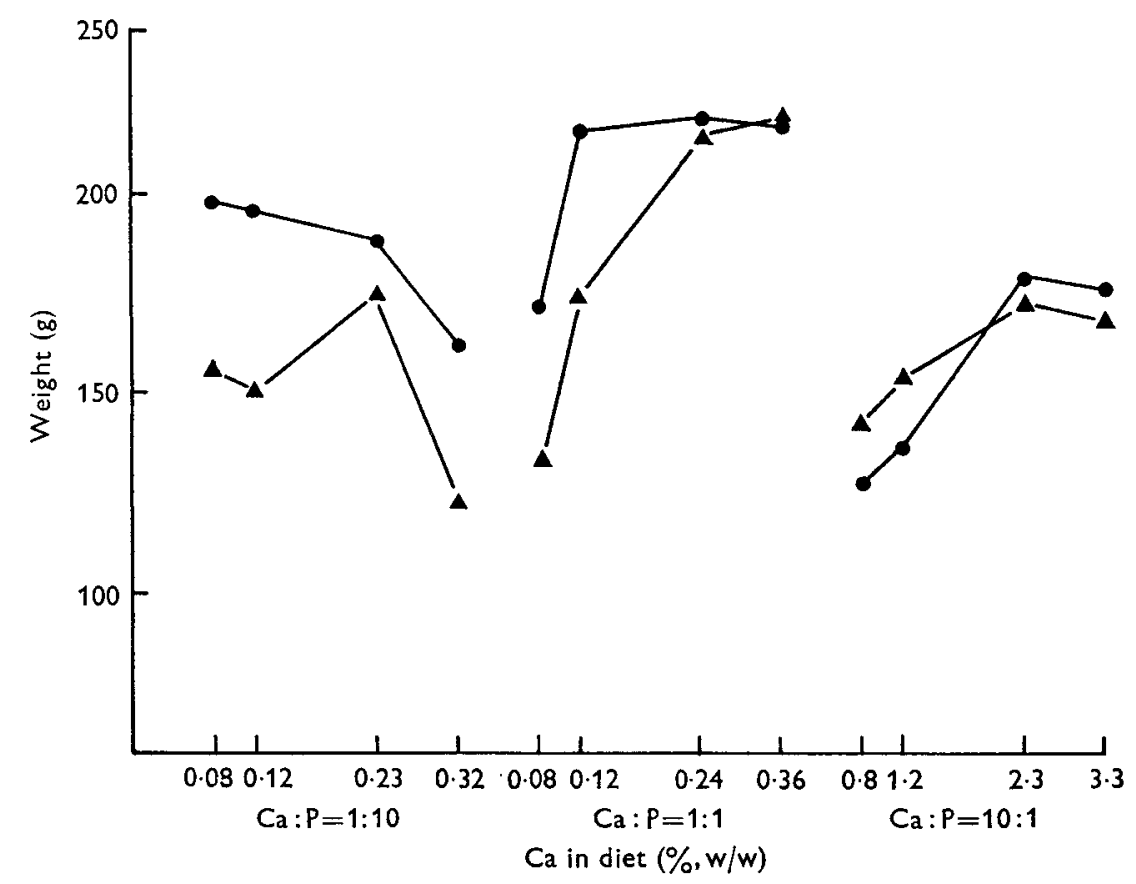

Fig. x. Effect of vitamin D on the final body-weight of rats at different levels of mineral intake and with a calcium to phosphorus ratio of $I: 10$ (left), I:I (centre) and IO:I (right). $\Delta-\boldsymbol{A}$, without vitamin $\mathrm{D}$; - , with vitamin $D$. In this and all Figures, values for the Ca:P ratio $\mathrm{I}:$ io and IO: I are derived from Harrand \& Hartles (1968, I969).

The apparent effect of the vitamin on serum $P$ concentration is quite different; at a Ca to $P$ ratio of $I: I 0$ the serum $P$ is lowered, at a ratio of $I: I$ it is not significantly changed, and at a ratio of IO: I the serum $P$ level is raised by provision of vitamin $D$.

When the dietary mineral content is increased, there is no corresponding increase in serum $\mathrm{Ca}$ concentration provided that the animals are receiving vitamin $\mathrm{D}$. The very low serum $\mathrm{Ca}$ concentrations occur only when there is a deficiency of both $\mathrm{Ca}$ and vitamin $\mathrm{D}$. In contrast, serum $\mathrm{P}$ concentration rises with increasing dietary intake of $\mathrm{P}$ at each $\mathrm{Ca}$ to $\mathrm{P}$ ratio. In general terms, therefore, it can be stated that serum $\mathrm{Ca}$ concentration is affected more by vitamin $\mathrm{D}$ than by dietary $\mathrm{Ca}$ content at each of the three dietary $\mathrm{Ca}$ to $\mathrm{P}$ ratios. On the other hand, serum $\mathrm{P}$ concentration is affected to a much greater degree by dietary intake of $P$ and less by the presence of vitamin $D$. Harrison \& Harrison ( 1960 ) administered vitamin D to rats fed on a diet of normal 
mineral composition but lacking vitamin $D$; they observed a persistent rise to normal in serum $\mathrm{Ca}$ and only a transient rise above normal in serum $\mathrm{P}$. They attributed this latter effect to vitamin $\mathrm{D}$, and its transient nature suggests that it was due to its mobilization along with $\mathrm{Ca}$ from the bone.

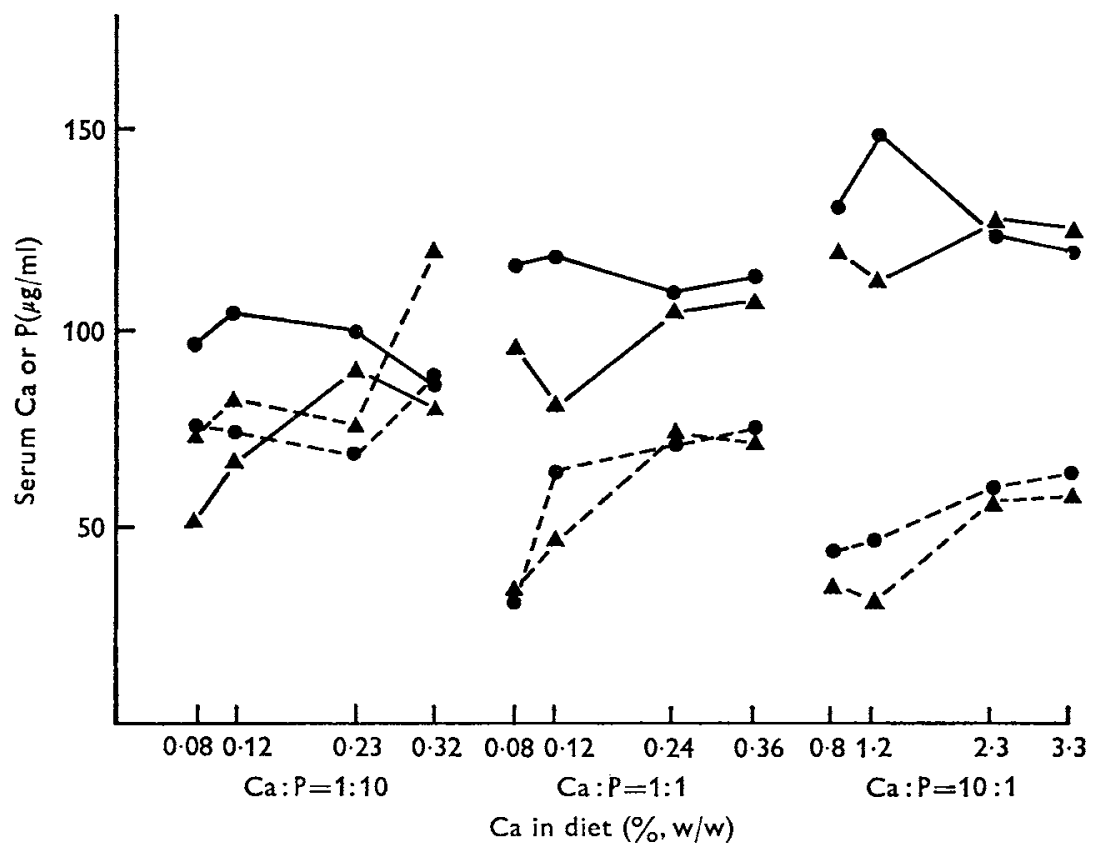

Fig. 2. Effect of vitamin $D$ on the serum calcium and phosphorus of rats at different levels of mineral intake and with a Ca to $P$ ratio of $I: I 0$ (left), I:I (centre) and $10: I$ (right). $\Delta-\Delta$, serum $\mathrm{Ca}$ without vitamin $\mathrm{D} ;-\longrightarrow$, serum $\mathrm{Ca}$ with vitamin $\mathrm{D} ; \boldsymbol{\Delta}---\boldsymbol{A}$, serum $\mathrm{P}$ without vitamin $D ; 0--0$, serum $P$ with vitamin $D$.

Bone formation, mineral intake and vitamin D. Fig. 3 shows the effect of vitamin D and increasing dietary mineral on the fresh weight of the humeri at the different $\mathrm{Ca}$ to $\mathrm{P}$ ratios. Fig. 4 shows comparable values for dry weight and weight of ash in the humeri. When the $\mathrm{Ca}$ to $\mathrm{P}$ ratio in the diet is $\mathrm{I}$ : 10 , provision of vitamin $\mathrm{D}$ increases the fresh weight, dry weight and weight of ash in the bone, although in the latter two the effect vanishes when the absolute intake of mineral is lowest $(0.08 \% \mathrm{Ca})$. When the $\mathrm{Ca}$ to $\mathrm{P}$ ratio is $\mathrm{I}: \mathrm{I}$ or $\mathrm{IO}: \mathrm{I}$ and there is a deficiency of $\mathrm{P}$ in absolute terms $(0.08$ or $0.12 \%$ ) the provision of the vitamin reduces the fresh weight of bone; when the intake of $\mathbf{P}$ is increased this effect is reversed (Fig. 3). There is some indication that the provision of vitamin $\mathrm{D}$ also reduces the dry weight of bone formed when dietary $\mathrm{P}$ is very low at a Ca to $P$ ratio of IO: I, but the weight of ash is not significantly changed by the vitamin (Fig. 4).

When the $\mathrm{Ca}$ intake is very low and the $\mathrm{Ca}$ to $\mathrm{P}$ ratio also very low ( $<\mathrm{I}: \mathrm{IO})$ in the absence of vitamin $\mathrm{D}$ the bones formed in the young growing rat are osteomalacic (Harrison \& Fraser, 1960; Ferguson \& Hartles, 1963). Animals on a similar mineral 
intake but provided with vitamin $\mathrm{D}$, i.e. animals subject to a simple $\mathrm{Ca}$ deficiency, develop a condition that appears closer to osteoporosis than to osteomalacia. Harrand $\&$ Hartles ( 1968 ) confirmed these findings, and showed that the addition of vitamin D to a diet low in $\mathrm{Ca}(0.08 \%)$ but adequate in $\mathrm{P}(0.8 \%)$ caused a shift from osteomalacia

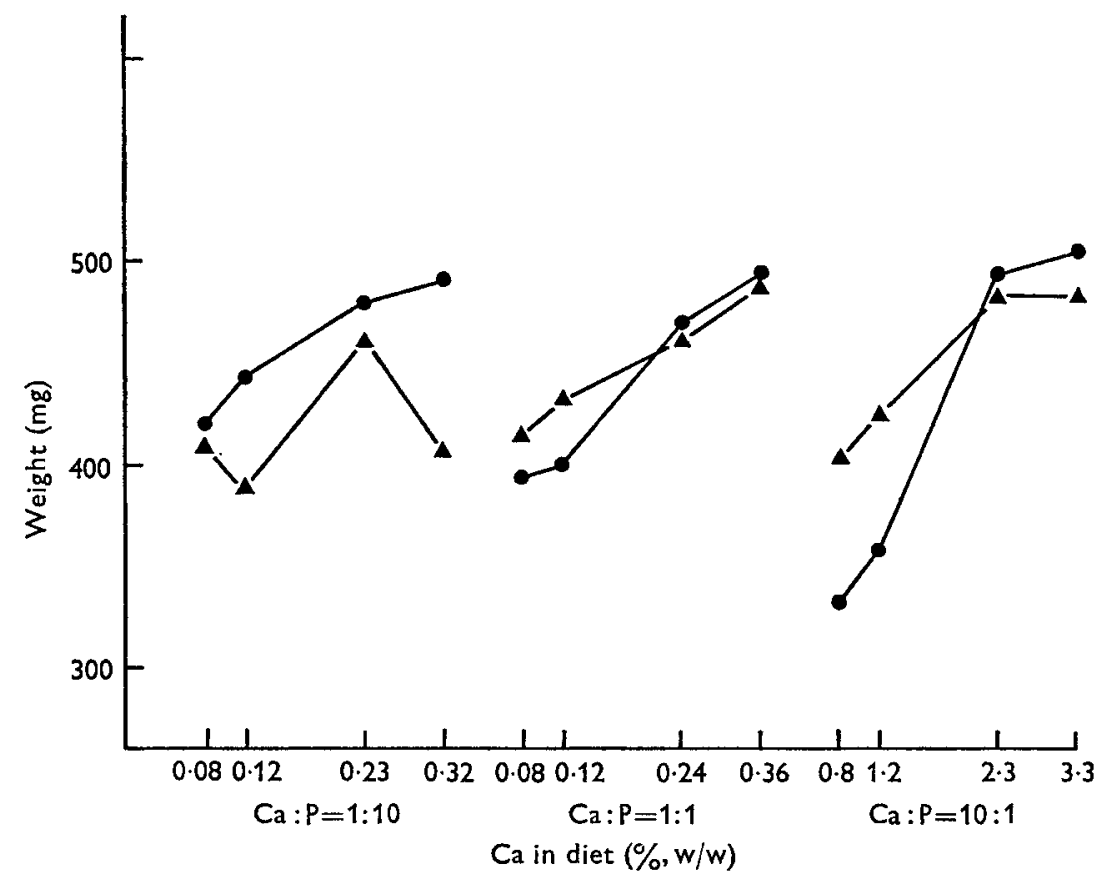

Fig. 3. Effect of vitamin D on the fresh weight of the humeri of rats at different levels of mineral intake and with a calcium to phosphorus ratio of $1: 10$ (left), I:I (centre) and $10: 1$ (right). $\Delta-\mathbf{\Lambda}$, without vitamin D; - , with vitamin $\mathrm{D}$.

to a porotic condition of the bone with demonstrably less osteoid. There was a concomitant large rise in serum $\mathrm{Ca}$ concentration, but no corresponding rise in the amount of ash deposited in the bone (Figs. 2 and 4 ). It seems reasonable to conclude, therefore, that in these circumstances, where the only mineral deficiency is of $\mathrm{Ca}$, the function of vitamin $\mathrm{D}$ is to potentiate the action of parathormone in maintaining $\mathrm{Ca}$ homoeostasis by mobilizing the skeletal mineral. That there is no demonstrable change in the mass of mineral ash in the bones is understandable, since the total $\mathrm{Ca}$ circulating in the blood of a rat is of the order of $\mathrm{I} \mathrm{mg}$. When the $\mathrm{Ca}$ intake is increased at the same $\mathrm{Ca}$ to $\mathrm{P}$ ratio of $\mathrm{I}: \mathrm{I}$, the vitamin has a decreasing effect on raising the serum $\mathrm{Ca}$ concentration, but significantly increases the actual amount of mineral deposited in the bone especially at the highest level of intake (Fig. 4). Thus, with increasing mineral intake at a $\mathrm{Ca}$ to $\mathrm{P}$ ratio of $\mathrm{I}: \mathrm{I} 0$ the calcaemic effect of vitamin $\mathrm{D}$ decreases, whereas the effect on deposition of bone mineral increases.

When the dietary $\mathrm{Ca}$ to $\mathrm{P}$ ratio is $\mathrm{I}: \mathrm{I}$ and the diet contains $0.08 \% \mathrm{Ca}$, vitamin $\mathrm{D}$ raises the serum $\mathrm{Ca}$ concentration to normal levels but is without effect on the low serum P (Fig. 2). The weight of mineral (ash) deposited in bone is very low (Fig. 4), 
and is raised slightly but significantly by vitamin $D$. At the higher levels of mineral intake both serum $\mathrm{Ca}$ and $\mathrm{P}$ levels are raised, bone mineral increases rapidly and the calcaemic effect of vitamin D becomes less. At low levels of mineral intake the fresh weight of the bone is decreased (Fig. 3).

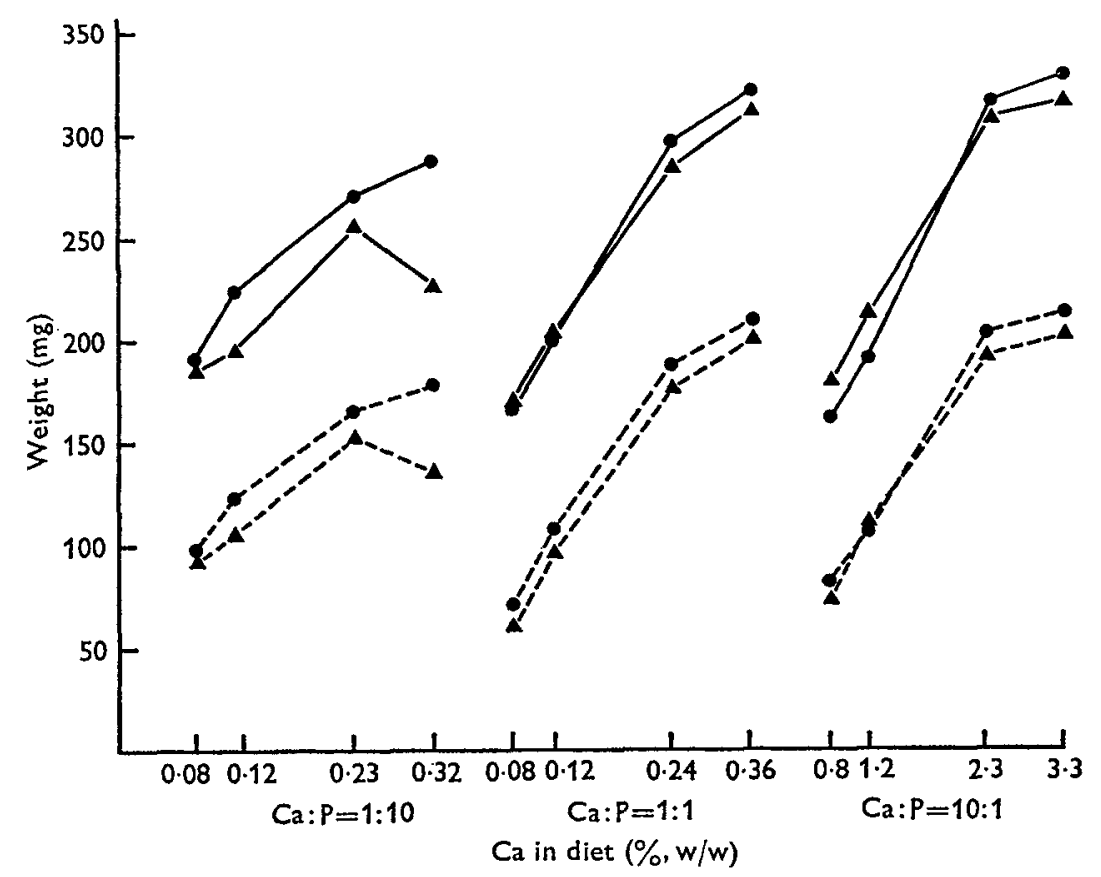

Fig. 4. Effect of vitamin D on the dry weight and weight of ash of the humeri of rats at different levels of mineral intake and with a calcium to phosphorus ratio of $\mathbf{I}: \mathbf{I} 0$ (left), $\mathbf{I}: \mathbf{r}$ (centre) and ro:I (right). $\Delta-\Delta$, dry weight without vitamin $D ;-\infty$ dry weight with

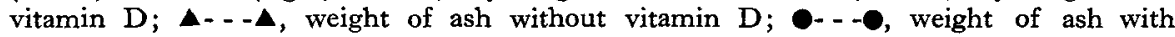
vitamin $\mathrm{D}$.

When the dietary $\mathrm{Ca}$ content is $0.8 \%$ or $\mathrm{I} \cdot 2 \%$ at a $\mathrm{Ca}$ to $\mathrm{P}$ ratio of $\mathrm{IO}: \mathrm{I}$, the serum Ca concentration is within the normal range even in the absence of vitamin $D$, whereas the serum $P$ concentration is grossly depressed. The provision of the vitamin raises serum $\mathrm{Ca}$ only when dietary $\mathrm{P}$ is grossly deficient and raises serum $\mathrm{P}$ at all levels but is without significant effect on the amount of mineral deposited (Figs. 2, 4). The increase in the percentage of ash in these circumstances is due to the reduction in the amount of organic matter and water in the bone. This trend is also apparent at the two lower levels of mineral intake at a $\mathrm{Ca}$ to $\mathrm{P}$ ratio of $\mathrm{I}: \mathrm{x}$. All these animals were rachitic. Underwood, Fisch \& Hodge (195I) considered that the rise in serum $P$ that followed administration of vitamin D to P-deficient animals was due to mobilization from the soft tissues, and that the vitamin accelerated the mineralization of bone. Our results (Harrand \& Hartles, I969) shown in Fig. 4 indicate no significant increase in bone mineral as a result of adding vitamin $\mathrm{D}$ to the diet. We cannot subscribe to the view that, in the rachitic state in the rat caused by a high $\mathrm{Ca}$ to $\mathrm{P}$ ratio in the diet, vitamin $\mathrm{D}$ 
causes a shunt of $P$ from the soft tissues to bone. It would appear from our results that there is no increased deposition of mineral attributable to vitamin $D$, and that the improvement, both histologically and chemically, is one of organization and utilization of mineral. The increase in percentage of ash and $A: R$ ratio is due mainly to a reduction in the non-mineral portion of the bone.

Incisor tooth formation, mineral intake and vitamin D. Fig. 5 shows diagrammatically the results for the dry weights and weights of ash in the incisor teeth in the present study ( $\mathrm{Ca}$ to $\mathrm{P}, \mathrm{I}: \mathrm{I}$ ) and in two earlier studies where the $\mathrm{Ca}$ to $\mathrm{P}$ ratios were $\mathrm{I}: \mathrm{I}$ o and I0: I (Harrand \& Hartles, I968, 1969). It is apparent that from the quantitative point

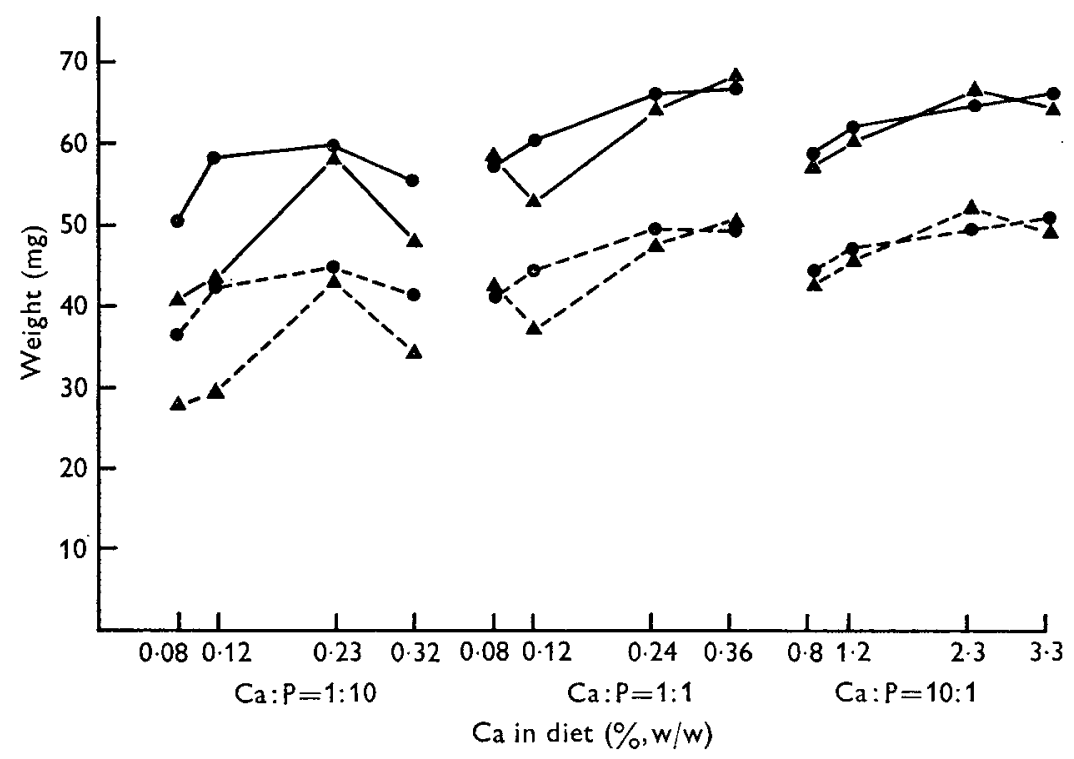

Fig. 5. Effect of vitamin D on the dry weight and weight of ash of the incisor tooth of the rat at different levels of mineral intake and with a calcium to phosphorus ratio of $I:$ Io (left), I : I (centre) and Io: I (right). $\mathbf{\Delta}-\boldsymbol{\Delta}$, dry weight without vitamin D; $-\mathbf{0}$, dry weight with vitamin $D ; \boldsymbol{\Delta}-\ldots$, weight of ash without vitamin $D ;-\ldots$, weight of ash with vitamin $D$.

of view the incisor tooth is most sensitive to lack of vitamin $\mathrm{D}$ when the diet is deficient in $\mathrm{Ca}$ at a $\mathrm{Ca}$ to $\mathrm{P}$ ratio of $\mathrm{r}: \mathrm{ro}$. The vitamin has least effect on the quantity of tooth formed when the $\mathrm{Ca}$ to $\mathrm{P}$ ratio is $\mathrm{ro:} \mathrm{I}$. It has been suggested that a simple deficiency of vitamin $\mathrm{D}$ results in a reduction of the amount of dentine formed (Jenkins, I966), and, by implication, that a possible function of the vitamin may be the control of the amount of dentine matrix formed. The results of these experiments show that in the rat vitamin $\mathrm{D}$ had no effect on the mass of tooth formed when the $\mathrm{Ca}$ and $\mathrm{P}$ content of the diet was 0.24 or $0.36 \%$ (Fig. 5). When the diet was low in $\mathrm{Ca}(0.08,0.12 \%$ ) at a $\mathrm{Ca}$ to $\mathrm{P}$ ratio of $\mathrm{I}: \mathrm{I} 0$, vitamin $\mathrm{D}$ greatly increased the mass of the tooth formed, but not when the Ca to $\mathrm{P}$ ratio was Io: $\mathrm{I}$ (Fig. 5).

Thus vitamin $\mathrm{D}$ increases tooth mass only when the supply of $\mathrm{Ca}$ is deficient or when the Ca to $P$ ratio is $I: r o$.

When the Ca to $\mathrm{P}$ ratio is I0: $\mathrm{r}$ (Harrand \& Hartles, 1969 ) provision of vitamin D 
does not affect the quantity of tooth formed but it has a marked qualitative effect in the microscopic appearance of the dentine. It would appear, therefore, that in these circumstances one function of the vitamin is to prepare the matrix for a more orderly deposition of the available mineral.

Variation in dietary mineral content has a less dramatic quantitative effect on the tooth than on the bone, except when vitamin $\mathrm{D}$ is absent from the diet and the $\mathrm{Ca}$ to $P$ ratio is $\mathrm{I}: \mathrm{ro}$. It is in these circumstances that the reactions of the tooth and bone show certain similarities (Figs. 4, 5).

Qualitatively, however, the teeth are severely affected by deficiencies of both vitamin $\mathrm{D}$ and mineral.

\section{Comparative effect of mineral intake and vitamin $D$ on the forming incisor tooth and bone}

There is evidence to show that developing teeth and bone react differently to dietary changes in Ca, P and vitamin D (Gaunt \& Irving, I940; Gaunt, Griffith \& Irving, I 942; Irving, 1957; McRoberts \& Hill, 1962; Ferguson \& Hartles, 1964, I966).

The formed tooth, unlike bone, is extremely resistant to metabolic change and does not undergo remodelling. The only physiological resorption that occurs in the erupted teeth is in the deciduous dentition prior to natural exfoliation. The forming tooth, on the other hand, is responsive to metabolic influences, in some respects (e.g. fluorosis) more so than bone (Sognnaes, I96r).

The results of the present work and of earlier studies (Harrand \& Hartles, 1968, 1969) can be summarized as follows.

(I) Lack of dietary mineral at $\mathrm{Ca}$ to $\mathrm{P}$ ratios of $\mathrm{I}: \mathrm{IO}, \mathrm{I}: \mathrm{I}$ and $\mathrm{IO}$ : I reduced the mass of mineral deposited in bone to a greater degree than in teeth.

(2) Variation of dietary mineral content had its least effect on tooth mass and weight of ash at a $\mathrm{Ca}$ to $\mathrm{P}$ ratio of 10: I. Bone mass and weight of ash, on the other hand, were least affected at a $\mathrm{Ca}$ to $\mathrm{P}$ ratio of $\mathrm{I}: \mathrm{IO}$.

(3) The mass of the forming tooth was more seriously affected by a poor dietary supply of $\mathrm{Ca}$ than by a lack of $\mathrm{P}$. The converse was true for bone.

(4) The consumption of diets high in $\mathrm{P}(3.2 \%)$ with normal $\mathrm{Ca}(0.32 \%)$ reduced the mass and amount of mineral deposited in both bones and teeth compared with diets containing $2.3 \% \mathrm{P}$ and $0.23 \% \mathrm{Ca}$. However, the provision of vitamin $\mathrm{D}$ mitigated this effect in the teeth and reversed it in bone. Thus an excessive intake of $\mathrm{P}$ has a more deleterious effect on teeth than on bone. An excessive consumption of $\mathrm{Ca}$ at a dietary $\mathrm{Ca}: \mathrm{P}$ ratio of Io: I had no such effect on either teeth or bones.

(5) In relation to the amount of mineral deposited in both bones and teeth, the effect of vitamin $D$ varied with the $C a$ to $P$ ratio in the diet. At a ratio of $I: I 0$ the effect of the vitamin was highly significant, at $I: I$ it was of less significance, and at Io: $I$ it was not significant.

(6) Notwithstanding the lack of quantitative effect of vitamin $\mathrm{D}$ at a $\mathrm{Ca}$ to $\mathrm{P}$ ratio of I0: I, there was a marked qualitative improvement in both bones and teeth. There is therefore a strong possibility that the vitamin exerts an effect on the organization of a calcifying tissue quite distinct from any function it may have in raising serum $\mathrm{Ca}$. 
It is postulated, therefore, that the calcaemic and mineralizing actions of vitamin $D$, though related, are independent effects.

Finally, it must be stated that the blocking by weight was effective in reducing residual variancy as the blocks removed a significant amount of the variation.

The authors wish to thank Mr R. P. Williams, Mr R. L. W. Connell and Miss Greta Rixom for the care of the animals and technical assistance, and Mr J. S. Bailie for the preparation of the figures.

\section{REFERENCES}

Ferguson, H. W. \& Hartles, R. L. (I963). Archs oral Biol. 8, 407.

Ferguson, H. W. \& Hartles, R. L. (I 964). Archs oral Biol. 9, 447.

Ferguson, H. W. \& Hartles, R. L. (1966). Archs oral Biol. I1, I345.

Gaunt, W. E., Griffith, H. D. \& Irving, J. T. (r942). F. Physiol., Lond. 100, 372.

Gaunt, W. E. \& Irving, J. T. (1940). F. Physiol., Lond. 99, I8.

Harrand, R. B., Green, R. M. \& Hartles, R. L. (1966). Br. F. Nutr. 20, 55.

Harrand, R. B. \& Hartles, R. L. (I 968). Br. F. Nutr. 22, 45.

Harrand, R. B. \& Hartles, R. L. (1969). Br. F. Nutr. 23, 523.

Harrison, H. E. \& Harrison, H. C. (r96o). In Bone as a Tissue p. 300 [K. Rodahl, J. T. Nicholson and E. M. Brown, editors]. London: McGraw-Hill.

Harrison, M. \& Fraser, R. (1960). F. Endocr. 21, I97.

Hartles R. L. \& Leaver, A. G. (1961). Archs oral Biol. 5, 38.

Irving, J. T. (1957). Calcium Metabolism. London: Methuen.

Jenkins, G. N. (1966). The Physiology of the Mouth. London: Blackwell.

McRoberts, M. R. \& Hill, R. (1962). Nature, Lond. 194, 92.

Sognnaes, R. F. (I961). In Mineral Metabolism Vol. I, Part B, p. 677 [C. L. Comar and F. Bronner, editors]. London: Academic Press.

Underwood, E., Fisch, S. \& Hodge, H. C. (195 I). Am. F. Physiol. r66, 387. 